\title{
Creating Sites of Community Education and Democracy: Henry Morris and the Cambridgeshire Village Colleges. A Reflection Ninety Years on from Their Inception
}

\author{
Neil Hopkins \\ School of Teacher Education \\ University of Bedfordshire, UK
}

\begin{abstract}
This paper investigates the work of Henry Morris (1889-1961), in particular his ideas on the Cambridgeshire Village Colleges. It is now ninety years since the first of these was founded in Sawston in 1930, and the paper aims to address the issue of whether Morris's views on education and democracy encapsulated in the Village Colleges still have relevancy in the early twenty-first century. An overview of Morris's career and the creation of the Village Colleges is investigated, using the work of Paul Hirst (1994) and associative democracy as a theoretical lens. It is argued that the Cambridgeshire Village Colleges do have some attributes of associative democracy, particularly their original emphasis as sites of local democracy and participation from voluntary bodies and private individuals. However, Morris's role as Cambridgeshire's Chief Education Officer (19221954) meant the local state (in the guise of the County Council) played a more significant role in the Village Colleges than Hirst advocates for his version of associative democracy. As English primary and secondary schools turn from local authority control to academy status, Morris's vision for local schools of and for local people is becoming increasingly compromised. The paper ends with the work of Allen and Gann (2018), both influenced by Morris, who argue for a revitalised form of comprehensive schooling and lifelong learning that again sees educational institutions as sites of grassroots democracy.
\end{abstract}

\section{Introduction}

As a resident of St Ives, I am technically outside the old county boundaries of Cambridgeshire - before the reorganisation of local government in 1974, the counties of Huntingdonshire (of which St Ives was part) and the Isle of Ely were beyond the borders of Cambridgeshire ${ }^{1}$. The county was geographically smaller than it is now and the city of Cambridge had a very powerful cultural and economic hold over its hinterland of small villages and market towns. However, the influence of Henry Morris and the village colleges has stretched well beyond the confines of Cambridgeshire in the ninety years since they were founded. Morris wanted to establish educational and community institutions for those villages and market towns to enable them to survive and thrive in an increasingly industrial and technological world. His concern was that the attractions of Cambridge and other cities were stripping the rural areas of Cambridgeshire of their

\footnotetext{
${ }^{1}$ Strictly speaking, the Isle of Ely joined Cambridgeshire in 1965 - the reorganisation of local government at the national level in 1974 led to Huntingdonshire and the Soke of Peterborough merging into a larger Cambridgeshire.
} 
workforce and community spirit. The village colleges were Morris's attempt to bolster rural life through the guise of lifelong education.

What, if any, influence does Morris's example have for us in the twenty-first century? This paper will argue that the village college example, although devised for the Cambridgeshire context, offers possibilities for educational and democratic development in contemporary times. I will offer a brief overview of Morris's career and the village college as a concept and in practice before looking at the institution through the lens of Paul Hirst's (1994) depiction of associative democracy. My reason for choosing this particular framework in which to analyse Morris's ideas is that Hirst offers a theory of democracy and public services at the community level that is not reliant on a strong sense of the local authority or state. Hirst offers, instead, a view of public services that emphasises the need for civic or voluntary involvement in their governance and day-today running that offers a critique of the County Hall model that Morris espoused as a Chief Education Officer. The paper will then conclude with an exploration of recent views on democratic education by authors influenced by Morris (Allen and Gann (2018)) in the light of the academisation of primary and secondary schools in England.

\section{Henry Morris and the Village College Concept}

We are now ninety years on from the opening of Sawston Village College in 1930, the first in a proposed series of institutions Henry Morris planned for Cambridgeshire in his role as the county's Education Secretary (the title eventually changed to Chief Education Officer). In his influential Memorandum ${ }^{2}$ of 1924 , written to convince county councillors and other powerful figures in Cambridgeshire on the value and importance of the village college concept, Morris argued that it is education that offers a way forward from the perceived marginalisation of modern rural life and culture. He stated:

[l]f we wish to build up a rural civilisation that will have chronic vigour the first essential is that the countryside should have a localised and indigenous system of education in its own right (Rée 1984: 15).

However, Morris did not view education solely as something that occurs in childhood and adolescence in preparation for adult life - he had a very strong notion of education as a lifelong process and the village college as the centre within which a variety of community activities and pursuits would take place:

As the community centre of the neighbourhood the village college would provide for the whole man [sic], and abolish the duality of education and ordinary life. It would not only be the training ground for the art of living, but the place in which life is lived, the environment of a genuine corporate life. The dismal dispute of vocational and non-vocational education would not arise in it, because education and living would be equated (Rée 1984: 28).

What comes over powerfully in the passage quoted immediately above is the notion that education is a community activity and is not separated from other areas of local life - the village college, in Morris's sense, should be an articulation of local democracy. Morris made this meaning plain further on in the Memorandum when he wrote of the village college as

\footnotetext{
2 The Memorandum's full title is: The Village College: Being a Memorandum on the Provision of Educational and Social Facilities for the Countryside, with Special Reference to Cambridgeshire.
} 
the seat and guardian of humane public traditions, the training ground of a rural democracy realising its social and political duties ... Rural local government languishes because there is no institution that provides a centre of reference and a means of expression. The village college would meet that need (Rée 1984: 29, 30).

Morris wanted to avoid the village college becoming yet another instance of 'dual use' activity where educational buildings house school-age pupils in the daytime and adults in the evening without the sense of shared space and interaction between the generations that he hoped for. As an alternative to 'dual use' practice, he envisaged the village college 'becom[ing] something uniquely different - community, cultural and educational centres serving a broad spectrum of the local population' (Jeffs 1998: 60). Historically, adult education in England has operated independently of the state education system (see, for example, Thompson (2013) and Hopkins (2014)) whether through formal organisations such as the Corresponding Societies of the late 1700s, the SelfImprovement Societies of the mid 1800s and the Plebs' League of the early 1900s, or in more informal guises such as reading circles and groups. The Cambridgeshire village colleges was Morris's attempt to incorporate adult education into the culture and governance of an existing educational institution to prevent its perceived marginalisation and to articulate a sense of lifelong learning under one roof. Morris also wanted to harness the informal aspects of learning inherent in local clubs and societies by viewing the village colleges as the 'natural' habitat for such groups to meet. These clubs and societies provided, ideally, examples of intergenerational education where school students and adult learners could share and collaborate together.

In their original Cambridgeshire context, the village colleges were planned by Morris on the basis of the Fisher Act (1918) that made English secondary education compulsory up to the age of 14. In England, primary education (with a few local exceptions) has encompassed learning from years 5 to 11 . The village colleges were created as state secondary schools that taught students from the ages of 11 to 14 (increased to 15 (1944) and eventually 16 (1972)). What was perhaps unique about the Cambridgeshire village colleges was the idea of incorporating compulsory and postcompulsory education within one single institution. Morris envisaged the village colleges as a series of education and community hubs servicing a network of villages within close proximity. From 1930 to 1967, fifteen village colleges ${ }^{3}$ were created (another has recently been built in Camborne in 2013). Morris wanted the colleges to be pivotal in the political, creative and intellectual life of the villages to which they were associated. The community element even encompassed aspects of health with 'an ante-natal clinic and medical centre for health education' (Rooney 2013: 39) advocated for each village college. He had an almost mystical and messianic sense of the small market town, its surrounding hinterland and the presence of previous generations on the rural landscape:

The English country town of five to seven thousand with its surrounding villages is an ancient economic and social unit that has come down to us from the Middle Ages: it awaits a rebirth at our hands (Rée 1984: 108).

In terms of the curriculum for students in the compulsory phase of education at the village colleges, Morris was concerned with the academic/vocational divide that affected English state education at the time (and arguably still does). According to Rée,

\footnotetext{
${ }^{3}$ The Cambridgeshire village collages are: Sawston (1930), Bottisham (1937), Linton (1937), Impington (1939), Arthur Mellows Glinton (1949), Bassingbourn (1954), Swavesey (1958), Soham (1958), Melbourn (1959), Comberton (1960), Cottenham (1963), Sawtry (1963), Witchford (1964), Gamlingay (1965), Burwell (1967) and Cambourne (2013).
} 
[Morris] approved of the system by which pupils ... were introduced to theory through practice ... and by which engineering, the crafts and other practical subjects were given the same status as academic subjects (Rée 1973: 80.

What is striking is how close these views are to John Dewey (a near contemporary of Morris) in works such as Democracy and Education (1916) and Experience and Education (1938). What is equally notable is the lack of 'reference to Dewey in [Morris's] writings nor in his extant speeches' (Rée 1973: 80). Several commentators (notably Jeffs and Rée) have spoken of Morris's reluctance to acknowledge the influence of others and the inability to offer a nod to Dewey's work might be another instance of this trait. Morris appeared to be sympathetic to the idea of comprehensive secondary education - he noted that

[a] disabling weakness of the post-primary school is its isolation and its divorce from the real word of action ... We have to discover the contemporary equivalent to the element of reality which is provided by the apprenticeship system [emphasis in the original] (Rée 1984: 76-77).

Again, the ideas, if not the exact language, is strikingly similar to Dewey's theories of knowledge and education, especially the sense of a continuous dynamic between theory and practice and the life of 'occupations' (Dewey 2007: 109). According to Jeffs, 'Village Colleges to varying degrees seized [the] unique opportunity for experimentation' (Jeffs 1998: 50) offered to them between the abandonment of the 1926 National Code and the introduction of the National Curriculum in 1988. The tripartite system implemented through the 1944 Education Act was accommodated within the village colleges by the creation of a grammar 'stream' to ensure those pupils who passed the 'eleven plus' could remain with their secondary modern peers in the one institution whilst also facilitating, theoretically, easy movement and transition between the streams. It is debatable whether this compromise (partly to prevent parents from the villages opting for the Cambridge grammar schools) weakened the sense of local collectivity and democracy Morris espoused for the village colleges and thoughts of a genuinely comprehensive curriculum for all.

One of the concepts Morris coined during his time as the Cambridgeshire Chief Education Officer was the 'pedagogic fallacy'. This term encapsulated Morris's belief that children should not be introduced to learning they were not ready for. In his paper 'PostWar Policy in Education', Morris explains: 'the pedagogic fallacy [consists] of projecting the intellectual and aesthetic understanding of maturity into the minds and personalities of young people under 16 or 18' (Rée 1984: 69). Whether this is seen as educational good sense or a hint of Morris's patrician character will depend on the reader but it is something he set great store by and regarded as a recurring defect in teacher education of the period. One of the means of overcoming such a fallacy was closer cooperation between universities (as centres of educational training and research) and the schools they served within the locality - such ideas were extensions of Morris's belief of theory in action and centres connecting and energising agents within their ambit.

Morris's legacy went beyond the boundaries of Cambridgeshire. He had an unerring ability to cultivate and support young educational administrators - Rée has spoken of 'a long line of "apprentices" who Morris took on at Shire Hall' (Rée 1973: 35) who then went on to occupy important roles in educational offices across English local government. In terms of Morris's vision of village colleges and community education, the take up was mixed - the most successful example of cross-pollination was Leicestershire. Rée, discussing the views of Stewart Mason (the post-Second World War Chief Education Officer of Leicestershire, states: '[Mason] echoed Morris in developing the point that the 
village college idea need not be confined to a rural setting' (Rée 1973: 136).

Leicestershire was to adapt and develop Morris's concept to include urban centres (thus renaming the institutions as 'community colleges' in the process). Devon,

Nottinghamshire, Derbyshire and Somerset were other local education authorities who significantly embraced the village college as a whole or in part.

But what of the original Cambridgeshire versions? How have they lived up to Morris's vision after their inventor left the scene? Jeffs, for one, has been critical of the village colleges, calling them 'a profound disappointment because they are so like other schools' (Jeffs 1998: 78). Rooney, however, lays the blame more squarely on government policy from the 1980s onwards for the difficulties the village colleges have encountered (especially with regards to adult education) and still sees them as vehicles of hope in what is often difficult educational territory:

The benefits of community education are difficult to inspect, to codify, to test and put into league tables, and increasingly it was reduced or sidelined. In most of Cambridgeshire the Village College ethos was strong enough to continue the fight for community education and all it stood for, and most Colleges still strive to serve the local community (Rooney 2013: 84).

The issue of the increasing centralisation and fragmentation (and how they have affected Cambridgeshire village colleges) will be explored in more detail in a later section.

\section{Associative Democracy and its Application to Education}

Associative democracy is a political theory where power, particularly in the organisation and facilitation of public services, is devolved (where possible) down to the grassroots level to ensure these services are meeting the needs of the people who are using them and also as a form of reinvigorating local democracy. According to Paul Hirst:

The principal aim of an associative supplement to representative democracy is to reduce both the scale and the scope of the affairs of society that are administered by state agencies overseen by representative institutions (Hirst 1994: 68-69).

There has been a trend in many countries over the past several decades to centralise the education system in a bid to maintain academic 'standards' and provide a uniform curriculum in order to facilitate cultural cohesion and increase economic productivity (Hopkins 2019). Hirst has spoken about the impact of centralisation and state control on public services, offering associative democracy as an alternative model:

Big government has grown at the expense of individual rights and freedoms. The attempted uniformity of state policy and forms of social provision has meant the imposition of common rules and standard services on the increasingly diverse and pluralistic objectives of the members of modern societies ... Associations, by contrast, empower those for whom services are provided in diverse ways.

Voluntary association is an alternative to top-down bureaucracy in the competent provision of services (Hirst 1994: 20, 21).

So, in the model depicted by Hirst, public services are not simply deregulated to local authorities in a movement down from national to local bureaucracies - he envisages something more radical, a situation where bodies that do not belong to either the central or devolved state have significant power determining the direction in which education (or 
other public services) takes in a particular environment. In this sense, associative democracy is an ongoing interaction between the state and civil society regarding the organisation of public services in a given locality.

In some senses, Hirst's version of associative democracy draws upon the heritage of the mutual and cooperative societies of the nineteenth and early twentieth centuries. These societies were formed from the efforts of individual communities to alleviate the sting of poverty and help their members to lead fuller lives without the support of central or local government. In Hirst's words:

Associationalism makes a central normative claim, that individual liberty and human welfare are both best served when as many of the affairs of society as possible are managed by voluntary and self-governing associations (Hirst 1994: 58).

The creation of charity schools and schools run on public subscription prior to the adoption of the 1870 Education Act are historical examples of this kind of associationalism in action in an educational context - one thinks of the Mechanics Institutes in the larger English cities or various cottage schools throughout rural counties. In more recent times, the establishment of schools and colleges by religious and cultural communities not covered by the 1944 Education Act or by groups influenced by anarchist thinking offer evidence of associationalism in practice (the Modern School movement based on the philosophy of Francisco Ferrar is one example). According to Suissa, '[a] central animating ideal [for anarchism] is that of the free society, based on mutual cooperation, decentralisation and self-government (Suissa 2006: 25). These ideals are very close to those espoused by Hirst's version of associationist although Hirst would probably deviate from much anarchist thinking through his belief in an established role for the state in the provision of education and other public services.

Where, perhaps, Hirst's theory is weakest is on the issue of coordination. If education systems are to be run primarily on a voluntary basis that involve more than one school (say), then providing services that link these can prove difficult (one has only to think of the problems some multi-academy trusts have had with connecting services and information between the component schools, for instance). Hirst's solution to this is to envisage, ultimately, a mature 'associationist state' where '[v]oluntary associations would enter into public governance in a decentralized state (Hirst 1994: 472-473). The issue is how services are coordinated in the meantime. Hirst does suggest some input from local or central government which then begs the questions regarding how 'associationist' a system can be when the state has a significant say in the way public services are administered.

\section{Morris, the Village College and Associative Democracy}

The Cambridgeshire Village Colleges as conceived by Morris clearly have some attributes of associative democracy. The emphasis on the locality as a centre of power is something, as we have seen above, Morris was deeply sympathetic to. He viewed village colleges through the lens of active citizenship and local democracy. However, Morris had a more complicated view of the relationship between the state and the locality than is often found with advocates of associative democracy such as Hirst. In the words of Rée: 
[Morris] emphasis[ed] his faith in the concept of state education as found in Britain, where schools are locally administered and only in part financed - and therefore only in part controlled - by central government (Rée 1973: 79).

Morris was himself a bureaucrat, albeit one based at Shire Hall in Cambridge rather than Whitehall. His role required careful negotiation of vested interests in the Ministry of Education, the education committee of Cambridgeshire County Council and influential opinion formers in the region. The significant effort Morris needed to expend in order to take his village college concept from idea to reality (including fundraising trips to philanthropic donors in the United States) meant that, over time, the village colleges became akin to a crusade in his mind. Jeffs neatly articulates the conundrum between Morris's desire to improve the quality of life in rural Cambridgeshire and the need to maintain his vision (at the possible expense of differing perspectives):

Here was an administrator bent upon creating a better world in his own image, determined in the process not to relinquish his power. By inclination and training Morris was a centralizer [my emphasis] (Jeffs 1998: 37).

So what we have, at heart, is something of a contradiction. On the one hand there is the powerful depiction of an institution that will integrate public services at the point of need, where local debate and decision making is facilitated and encouraged to crystallise. On the other, there is the visionary who is unable and unwilling to let go of his grand scheme even though this attitude is itself a negation of the democratic process (Morris's sense of an 'Ideal Order').

Does this contradiction fatally compromise the connection I am attempting to make between the Cambridgeshire village colleges and associative democracy? Not necessarily - although Morris had a tendency, as we have seen, towards control and centralisation, this does not negate the very real sense of local empowerment the village colleges engendered after they were established. Recounting the opening of Swavesey Village College in 1959, Rooney writes:

From the start, community education flourished and grew vigorously. The first community tutor recalled how on the first enrolment evening, 500 people came to the College to enrol in evening classes and clubs, and this grew and expanded year on year - proving what a fierce longing for culture, entertainment, for opportunity there had been across the rural communities (Rooney 2013: 59).

Associative democracy, by its very nature, places emphasis on the associations that form part of civil society. It often views the state as a partner or facilitator of public services rather than determiner or provider. As Hirst states:

Associative reform would thus gradually change the primary role of government from that of a service provider to a means of ensuring that services were adequately provided and the rights of citizens and associations protected (Hirst 1994: 64-65).

The Cambridgeshire village colleges were never conceived as being completely voluntary organisations - they were a partnership between the local authority (as the provider of compulsory education) and various bodies interested in adult and community learning. Indeed, Morris himself viewed the relationship in partnership terms:

The village college will thus associate the voluntary associations of the countryside with the administration of statutory services, so that these benefits 
may be fully appropriated by the community, and supply more effectively adjusted to demand (Rée 1984: 27).

So it would be fair to say that the village colleges had (and continue to have) aspects of associative democracy rather than viewing them as exemplars of it in terms of Hirst's definition. Hirst's vision of an associative welfare system as 'a dispersed decentralized democracy' (Hirst 1994: 504) goes beyond the vision of Morris for a local authority coordinating services within its boundaries.

\section{Cambridgeshire Village Colleges and the Contemporary Educational Context}

As stated earlier in this article, we have now reached the ninetieth anniversary of the opening of the first village college in Sawston in 1930. The educational landscape that these institutions now inhabit is a very different one from the time of Morris's tenure as Chief Education Officer. As one author has stated recently (Hopkins 2019), in many educational jurisdictions the prevailing ideology over the past few decades has been variations of neoliberalism - the increasing centralisation of the curriculum alongside national inspectorates with a widening remit on standards; schools and colleges competing with one another for students and funding; a greater emphasis on parental choice. The English context has seen these elements play out to a particularly marked degree and this has inevitably impacted on the village colleges and Morris's vision for them.

Perhaps the most significant change, from Morris's point of view, has been the steady erosion in the responsibilities of local education authorities (LEAs). The implementation of the National Curriculum in the late 1980s was the first major step in the trend towards power being concentrated within the education ministry itself. The LEAs were further emasculated with the advent of 'academisation', a process that enables schools to opt out of local authority control and receive their funding directly from central government (HM Government 2010). According to the House of Commons Committee of Public Accounts:

As of January 2018, the Department for Education ... had converted around 7,000 maintained schools to academies; $72 \%$ of secondary schools are now academies (House of Commons Committee of Public Accounts 2018: 4).

In late 2019, only two village colleges still remained in local authority control (Arthur Mellows in Peterborough Local Authority and Burwell in Cambridgeshire Local Authority) - the other colleges are now part of various academy trusts ${ }^{4}$. It is important to note that academy trusts come in a range of shapes and sizes, from a small chain of two or three local schools to huge trusts that encompass dozens of schools across very large geographical areas. The governance and sponsorship of such trusts can also vary with

\footnotetext{
${ }^{4}$ Cambridgeshire Village Colleges and academy/local authority status (as of November 2019):

Sawston - Anglia Learning; Bottisham - Anglia Learning; Linton - Chilford Hundred Education Trust; Impington - Morris Education Trust; Arthur Mellows - Peterborough Local Authority; Bassingbourn - Anglia Learning; Swavesey - Cambridge Meridian Academies Trust; Soham Staploe Education Trust; Melbourn - Cam Academy Trust; Comberton - Cam Academy Trust; Cottenham - Astrea Academy Trust; Sawtry - Cambridge Meridian Academies Trust (now renamed Sawtry Village Academy); Witchford - Morris Education Trust; Gamlingay - Cam Academy Trust (now part of Gamlingay Village Primary); Burwell - Cambridgeshire Local Authority (renamed Burwell Village College Primary School); Cambourne - Cam Academy Trust
} 
some trusts having a local or religious focus whilst others have stronger connections to the business or industrial sectors.

Morris would have had no difficulty with schools collaborating with one another. In the Memorandum, he states:

There must be a grouping and co-ordination of all the educational and social agencies, whether statutory or voluntary, which now exist in isolation in the countryside; an amalgamation which, while preserving the individuality and function of each, will assemble them into a whole and make possible their expression for the first time in a new institution, single but many-sided, for the countryside (Reé 1984: 17-18).

Morris saw the benefits of pooling public and civic facilities to enable communities to receive the best possible services. The concerns he would have had with schools achieving academy status and organising themselves into academy trusts was less the sharing of expertise and concentration of scarce resources; the issue is more the fear of local communities losing a forum in which to debate and decide upon initiatives and priorities that are important to them. Morris, due to his lifelong involvement with local administration, was particularly sensitive to the potential role county and district authorities play in helping to facilitate democracy at the grassroots level. I have, however, already identified in the section above the complicated attitudes Morris had regarding the local state and institutions within its circle of responsibility.

As has been noted recently, 'local education authorities were not always exemplars of local democracy' (Hopkins 2019: 3) and it is important to neither over-romanticise nor vilify the effects local education authorities had upon their host communities. However, as Andrew Allen and Nigel Gann have noted, the move away from local authority control to academy trusts is not without serious concerns regarding community control and democratic accountability. Allen and Gann contend that the academisation of English primary and secondary schools 'has created myriad autonomous and privatized edubusinesses that have reduced or eliminated stakeholder involvement and democratic engagement' (Allen and Gann 2018: 218). Allen and Gann argue for the 'reformation of the school into a learning community' (Allen and Gann 2018: 222) based on the principles of empowered participatory governance that encompass 'bottom-up participation, deliberative solution generation and practical orientation' (Allen and Gann 2018: 222). These authors have identified possibilities for establishing a more democratic form of governance even within the English academy structure where they describe a 'co-operative academy' in which the various stakeholder constituencies are encouraged to become members and participate in the election of a co-operative forum and the nomination of governors (trustees) (Allen and Gann 2018: 223).

In what sense are Allen ${ }^{5}$ and Gann's proposals similar or different to the model of associative democracy advocated by Hirst? Clearly, there are areas where the two theories significantly overlap, especially where Allen and Gann talk of 'new channels ... established for those most directly affected by the targeted problem' (Allen and Gann 2018: 222). Hirst has stated:

Associative democracy by 'publicizing' the private sphere, through democratically-controlled voluntary associations, would not trespass on individuals' liberties, but would enhance them by providing citizens with greater control of their affairs in the economy and in welfare (Hirst 1994: 74).

\footnotetext{
${ }^{5}$ Interestingly, Andrew Allen was an Assistant Warden at Impington Village College, one of Morris's earliest (1939).
} 
So, there is agreement that public services (including education) would benefit from greater involvement and control by those citizens who use or are directly affected by these services. However, there are also significant differences between the work of Hirst and what Allen and Gann are advocating (and, by extension, what Morris stood for) in terms of the relationship between schools and the local and national authorities. For what Hirst is advocating is a movement away from national and local authority control to a state of affairs where civic and voluntary bodies have, perhaps, the primary say on how services are organised. As we have seen, Hirst is not resistant to all forms of state participation - his concern (as I highlighted earlier) is that

[b]ig government has grown at the expense of individual rights and freedoms. The attempted uniformity of state policy and forms of social provision has meant the imposition of common rules and standard services on the increasingly diverse and pluralistic objectives of the members of modern societies (Hirst 1994: 22).

It is doubtful that Hirst would be in favour of academisation as it has been conceived by the UK's Department for Education - his concern over the lack of local governance and accountability is likely to be as strong as Allen and Gann's. Where the two viewpoints differ is on how much power should be placed in the hands of local government. Allen and Gann share Morris's belief in the 'tempering influences of local government power' (Allen and Gann 2018: 221). Echoing the sentiments of Morris and his vision of the village college, the authors advocate

An open participatory model where continued popularisation of democratic models of community culture are embedded. We would argue ... that a truly comprehensive school does not only offer open access to pupils and open up its facilities to the wider public, offering appropriate educational, social and leisure facilities to the community - it also enables, encourages and continuously develops local lay participation in its governance (Allen and Gann 2018: 221).

One of the major concerns in Cambridgeshire schools reverting from local authority control to governance by academy trusts is this perceived lack of local participation and accountability, a mainstay of Morris's view of lifelong education in the county.

\section{Conclusion}

Ninety years on from the opening of Sawston Village College by the then Prince of Wales (later Edward VIII), what is Henry Morris's relevancy to education today? I have argued that Morris offers a complex heritage in which to explore the issue of democratic education. As noted by Jeffs (1998), he was both a centralizer and a believer in grassroots democracy. This paradox is partly a result of Morris's role as Chief Education Officer of Cambridgeshire and partly a blend of elitist and democratic values within the man himself. This tension between the local state and the community is heightened by looking at the village colleges through the lens of Hirst's version of associative democracy. I have argued that the village colleges did, in their original composition, share some attributes of associative democracy (especially the emphasis on voluntary community participation in how the village colleges were administered and who they served). However, the village colleges, due to their attachment to the local education authority at the time of their founding and for a long period afterwards, do not follow Hirst's model of associative democracy in its entirety. 
The change of governance regarding English primary and secondary schools over the past few decades has had implications for the village colleges and Morris's vision for them. It has been noted that most colleges have now adopted academy status and are no longer in local authority control. This process has been criticised by Allen and Gann (2018) as a movement away from Morris's conception of the village colleges as centres for local democracy towards an increasingly neoliberal business-like model. The authors, influenced by Morris's example, offer a renewed version of the comprehensive school as a site for local democracy and lifelong education.

\footnotetext{
* The author would like to acknowledge the support of the Philosophy of Education Society Great Britain on whose Writing Retreat (September 2019) he was able to complete much of the research that went into this project. I would also like to offer my gratitude to the Henry Morris Memorial Trust (especially Peter Hains and Lesley Morgan) for their kindness in locating and sending research material. I am grateful for the comments of anonymous reviewers during the peer review process which led to improvements to this article.
}

\section{References}

Allen, A. and Gann, N. (2018), Embedding Democratic Engagement in School Leadership: comprehensive schooling structures in an academized system, Forum, 60 (2): 217-228.

Dewey, J. (2007 [1916]), Democracy and Education, Teddington: Echo Library.

HM Government (2010, Academies Act (2010) [online]. Available at: http://www.legislation.gov.uk/ukpga/2010/32/ (Accessed: 18 November 2019).

Hirst, P. (1994), Associative Democracy: New Forms of Economic and Social Governance [electronic book], Cambridge: Polity Press.

Hopkins, N. (2014), Citizenship and Democracy in Further and Adult Education, Dordrecht: Springer.

Hopkins, N. (2019), Democratic Socialism and Education: New Perspectives in Policy and Practice, Dordrecht: Springer.

House of Commons Committee of Public Accounts (2018), 'Converting schools to academies: Fifty-Second Report of Session 2017-19' (HC697) [online]. Available at:https://publications.parliament.uk/pa/cm201719/cmselect/cmpubacc/697/697.pdf (Accessed 5 November 2019).

Jeffs, T. (1998), Henry Morris: Village Colleges, Community Education and the Ideal Order, Nottingham: The Educational Heretics Series.

Rée, H. (1973), Educator Extraordinary: The Life and Achievement of Henry Morris, London: Longman.

Rée, H. (1984) (ed.), The Henry Morris Collection, Cambridge: Cambridge University Press. 
Rooney, D. (2013), Henry Morris, The Cambridgeshire Village Colleges and Community Education, Sawston: The Henry Morris Memorial Trust.

Suissa, J. (2006), Anarchist Education: A Philosophical Perspective, London: Routledge.

Thompson, E. P. (2013 [1963]), The Makings of the English Working Class, London:

Penguin. 